IRSTI 06.51.65

\author{
Rakhmetzhan Anargul ${ }^{1}$, Medukhanova Lyazipa ${ }^{2}$ \\ ${ }^{1}$ lecturer of the Chair of the Department of International Relations and World Economy, \\ Department of International Relations, Al-Farabi Kazakh National University, \\ Almaty, Kazakhstan, e-mail: Rakhmetzhan.anar@gmail.com, tel.: +7 7781985177 \\ 2acting as associate professor of the Chair International Relations and World Economy, \\ Department of International Relations, Al-Farabi Kazakh National University, \\ Almaty, Kazakhstan, e-mail: medukhanova.1@gmail.com, tel.: +7 7017586230
}

\title{
THE INFLUENCE OF DIGITAL MARKETING ON CONSUMER BEHAVIOUR
}

In the context of internationalization and globalization, the global business environment is rapidly changing under the influence of information technology and digital media. In this regard, understanding how to conduct business on the Internet nowadays is not only an integral part of the business but also an excellent way to grow the business itself. At the same time, consumers also receive a much broader range of products and services. In terms of building strong relationships and relationships with customers, marketers must first learn what their customers are. In general, it is obvious that digital marketing in any form has a positive impact on consumer behavior. Along with this, the digital revolution and the Internet raise threats for organizations and competitors. This article examines the problems of more effective management related to the development of the Internet and digital technologies in marketing activities. The processes of digital marketing are examined based on the analysis of the efficiency and global activities of the company «Alibaba Group».

Key words: digital marketing, customer behaviour, traditional marketing, SMEs (small medium size enterprize), international business, local business, customer expectation, cognitive models, Alibaba Group.

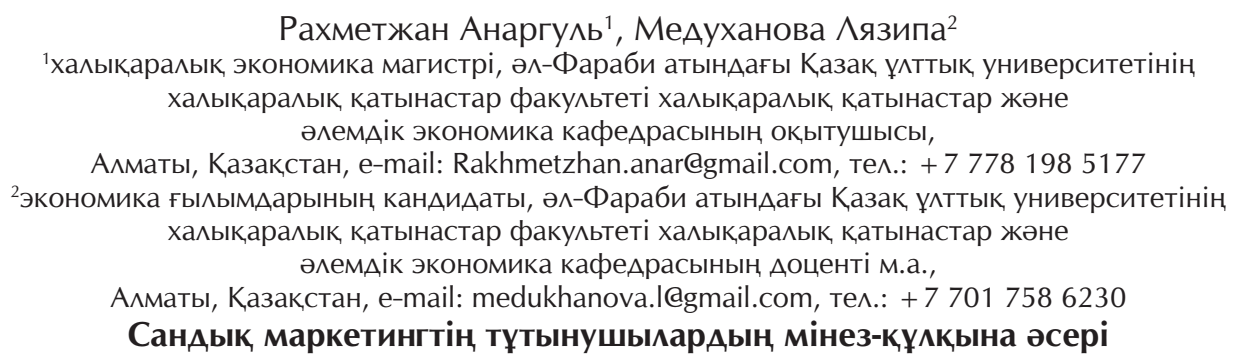

Интернационализация және жаһандану жағдайында әлемдік бизнестің ортасы ақпараттық технологиялар және сандық медиа әсерінен өте жылдам өзгеріп келеді. Осыған байланысты қазіргі таңда Интернетте бизнесті қалай жүргізу керектігін түсіну бизнестің ажырамас бөлігі ғана емес, сонымен қатар бизнестің өзін дамытудың үздік тәсілі болып табылады. Сонымен қатар, тұтынушылар сондай-ақ өнімдер мен қызметтерді әлдеқайда кең таңдау мүмкіндігіне ие болады. Клиенттермен берік байланыс пен қатынастарды құру көзқарасынан, маркетологтар алдымен олардың клиенттері кім болып келеді екенін танып білу міндетті. Жалпы және тұтас алғанда, қандай болса да түріндегі цифралық маркетинг тұтынушылардың мінез-құлығына жағымды әсерін тигізетіні күмәнсіз. Аемек, сандық революция және Интернет ұйымдар мен бәсекелестер үшін қауіптерді көбейтеді. Осы мақалада маркетингтік қызметте Интернет пен сандық техологияларды қолдануына байланысты неғұрлым тиімді менеджменттің мәселелері қарастырылады. Сандық маркетингтік үлерістер «Alibaba Group» компаниясының тиімділгі мен жаһанды іс-әрекетін талдау негізінде қарастырылады. 
Түйін сөздер: сандық маркетинг, тұтынушының мінез-құлқы, дәстүрлі маркетинг, SMEs (шағын және орта бизнес), халықаралық бизнес, жергілікті бизнес, клиенттердің күтуі, когнитивті модельдер, Alibaba Group.

\author{
Рахметжан Анаргуль ${ }^{1}$, Медуханова Аязипа ${ }^{2}$ \\ 'Казахский национальный университет им. аль-Фараби, \\ преподаватель кафедры международных отношений и мировой экономики, \\ г. Алматы, Казахстан, е-mail: Rakhmetzhan.anar@gmail.com, тел.: + 77781985177 \\ ${ }^{2}$ кандидат экономических наук, Казахский национальный университет им. аль-Фараби, \\ и.о. доцента кафеАры международных отношений и мировой экономики факультета международных \\ отношений, г. Алматы, Казахстан, e-mail: medukhanova.|Qggmail.com, тел.: + 77017586230
}

Влияние цифрового маркетинга на поведение потребителей

\begin{abstract}
В условиях интернационализации и глобализации мировая бизнес-среда весьма быстро изменяется под влиянием информационных технологий и цифровых меАиа. В связи с этим понимание того, как вести бизнес в Интернете, является на сегодня не только неотъемлемой частью бизнеса, но также и отличным способом роста самого бизнеса. В то же время и потребители также получают гораздо более широкий выбор продуктов и услуг. С точки зрения построения прочной связи и отношений с клиентами, маркетологи должны сначала изучить, что преАставляют собой их клиенты. В целом, очевидно, что цифровой маркетинг в мюбых формах оказывает положительное влияние на поведение потребителей. Наряду с этим цифровая революция и Интернет повышают угрозы для организаций и конкурентов. В Аанной статье рассматриваются проблемы более эффективного менеджмента, связанные с развитием Интернета и цифровых технологий в маркетинговой деятельности. Процессы цифрового маркетинга рассматриваются на основе анализа эффективности и глобальной деятельности компании «Alibaba Group».

Кмючевые слова: цифровой маркетинг, поведение потребителей, традиционный маркетинг, МСБ (малый и среАний бизнес), межАународный бизнес, местный бизнес, ожидание клиентов, когнитивные модели, Alibaba Group.
\end{abstract}

\section{Introduction}

The purpose of this work is to provide understanding of how digital marketing affects buying behaviour, and the decision making process as a part of consumer behaviour. Based on the existing literature and analytical materials, it is possible to research the problems of planning and organizing digital marketing strategies. Moreover, the issues of online marketing, business structure and the foundation of digital marketing strategies will be considered by analysing how Alibaba group highlights the significance of the digital marketing strategies.

In particularly, the cause of taking Alibaba group as a case study to analyse its digital marketing strategy is merely to suggest what kind of digital marketing and activities can achieve success in terms of a motivated group and customer behaviour.

Ultimately, main aim of this research topic is to consider the problem of how the digital marketing influence customer behaviour based on already proven literature, and also input new findings.

\section{Background and Methodology of Marketing Revolution in the Digital Age}

The research method used is a qualitative method, that is based on the different parts of peoples' lives, and their perception of peoples' behaviour, conduct and opinions. Additionally, the cross-cultural/comparative study is implemented, because it helps to examine the human behavior in the different cultural context. As a comparative cultural context, Chinese online retailer Alibaba group is used.

In the global new competitive and networked economy landscape, the digital space of social media network and new technology has totally revolutionized world business interaction. Therefore, the digital revolution is reshaping the economy as explained by B. Kellerman [1]. Moreover, digital revolution, information technology and social media affect all aspects of customer's study from planning strategy and penetrate the marketing mix, marketing communication and customer behaviour. Digital marketing excellence highlights the unique opportunities and support a range of organisational goals based on practical internet marketing. That is why the business environment significantly moving ahead faster and differently. Probably traditional marketing performances and theories are being turned on their head. Although digital technologies advance even faster, there is going to be more disruption in work, employment and more. Internationalization occurs when industries expand their research and development, trading, selling, production and 
business activities into international market, and the world of information technology, digital media and digital revolution are considered powerful platform for Internationalization. In fact, increasingly, our lives are spent online transaction, banking, shopping and in the social networks. Moreover, social media, Information Technology and digital revolution let human being jump into unique opportunities. Moreover, aggressively wireless communication, the internet and World Wide Web have been applied by not only organisations, but by the small medium enterprises globally. Although there is a big body of literature on the digital marketing platforms, there is a little number of studies on how the digital marketing processes or digital marketing strategies influence, develop and co-operate the consumer behaviour over time. Therefore, the lack of addressing knowledge in this perspective could be the reason why there are a significant number of difficulties that organisations or SMEs face. Alibaba group is taken as a case study to address the knowledge gap by examining and analysing its commercially successful digital marketing performance in terms of theoretical framework and available literature by D. Ariely [2].

\section{Findings of Adding Value by Measuring and Managing the Return on Investment in Customers}

It is important to note that most a quantitative research conducted via online data collection is not inherent in terms of the problem it is seeking to solve. In the sense of response rate, among 164 questionnaires that have been distributed, however only 138 were used for further analysis through PPSS (statistical package for the social science), Wechat (Chinese online software), Facebook and Twitter.

The innovation in the digital revolution where the traditional marketing got disrupted [3] the study of the consumer behaviour is a key to a successful marketing. Therefore, successful companies try to understand and recognise their buyer segment well. Because a better understanding of online customers led to recognition of different characteristics and attitudes to both acquiring new trends like buying online. Moreover, the same person would act differently in different situation. For instance, same customer would plan and act differently online than offline. However, in an offline marketing environment, there are a number tried and tasted techniques, which help marketers to understand how recipients have responded to communication by R. Baker [4].
G. Lee [5] describe that the internet and digital marketing made a shift from the traditional marketing to a business dynamics, which is beneficial, for example, small brands have opportunities to access to global market places and can attract customers all over the world in new efficient ways. On top of this, marketers, regardless of who are your best customers, need to understand customers' mind-set, customer's attitude and aspiration [6]. For example, every year 11th of November is considered as 'single's day' in China, so that day people try to shopping online crazy, because most of the products are discount and highly promoted. The e-buyers are different from the offline customers, because the online customers have power than ever before, initially, they have got more power, rights and time.

In the context of a strong communication and relationships with your customers, marketers should initially study who are your customers. A. Pickton [7] outline that surprisingly, not all online customers prepare to shop online than real physical shopping. They just try to get good deal and being in control. The key reason of online shopping may be the significance of little time availalbe. In fact, time saving can satisfy several needs simultaneously as the time saved can be spent fulfilling a range of unfilled needs. However, K. Wartimes al. [8] point out that some products such as electronic goods, tickets, clothes and books have higher percentage rate of online. It is not surprise that most of successful platform like Alibaba, offer key activities - entertainment, facilities of socializing, products information, purchasing and entertainment through search engine, email and chat, product guide and so on.

Shrinking the gap between customer's expectation and delivery is the successful managing customer's expectation [9]. On top of that, expectation can be managed by the entering into an informal or formal agreement as to what service the customers can expect through customer service guarantees. Ultimately, marketers in terms of findings above must deliver the service and support from physical fulfilment. An example for this, Alibaba customers are highly loyal, and make a definite choice to purchase a minority product. Moreover, online support services minimised the risks and give confident to customers. The best digital marketing platforms concentrate on how consumers deal with information, which include first stage is exposure. For example, if the content for present is not long enough, customers are not able to process it. If it changes too fast, the message will not be received. Second stage is attention. The human mind has limited capability to pick up everything in 
the screen. Therefore, marketers have to consider and test everything: colours, design and more.

Consumer behaviour is the initial study of from individuals to group, from group to organisations and the process how they select products, secure, use and dispose it, experience, service or knowledge to satisfy needs. These processes have impact on the not only consumer also society, which is overall view of consumer behaviour than traditional view, which is however attempting to concentrating on the buyer and final profit process. A great number of studies reveal two gaps between border view of consumer behaviour and traditional one. First, the traditional studies tended to concentrate and focus on full range benefiting and full filling customer's needs with excellent goods and service. Of course, whether goods or service is the first reason speak about customer behaviour. However, indirect influence on conception decision as well as the consequences beyond that. Studying consumer behaviour can be important for a number of reasons. To begin with, in market economies, business stand not for only purchasing products, organising service managing employee or building accounting system. B. Hawkins [10] pointed out that all marketing decisions or regulations are based on assumptions about consumer behaviour, which includes a focus on relationship between what people think, feel, and do. This statement can be based on consumer behaviour theories and models. As a matter of fact, it has been suggested five decision making classifications by different approaches: Economic Man, Psychodynamic, Behaviourist, Cognitive and Humanistic-typological. In particularly, Economic man introduces consumer behaviour, which is related to a great number of issues affecting purchasing and consumption activities. However, it has frequently been argued that these steps seen to be no longer considered as realistic decision-making outlines and that psychodynamic tradition is broadly influenced through 'Instinctive forces', that work beyond conscious though. On this point of view, S. Rachman [11] argues that psychodynamic approach is behaviour tend to be driven by biological factors, instead of environmental stimulation and individual cognition. Behaviourism illustrates that people's action, thought or felling, which are caused internal and external factors.

Coming up next, following will critically evaluate cognitive models of consumer behaviour, which will describe broad range of theoretical framework and consumer activities based on Alibaba group [11]. Social group and family demands special attention from consumer researchers. Modern and non-modern's elements have also affected the social group, resulting in a number of different aspects of family explained by K. Halvorson [12]. In many cases, the group behaviour of consumers affects the behaviour of an individual consumer. Therefore, many of decisions made by consumers are taken within the environment of the family and are thus affected by desire and attitude of other family members. Consumer can express individuality but within the safety of group. For instance, consumer from college and student seem to be more popular than others. In fact, they have access to a great number of resources. Because they are socialized and have known information like special privileges, expensive cars, top brands, generous allowances and more. Ultimately, they are more influenced on digital marketing and more. The sense of social class, customers normally grounded haves and havenots in terms of family background, income and occupation. Consequently, social class does affect the possibility of access to resources. That is why markets always segment customer base on those labels. A. Ott [13] argues that researcher do study based upon social class, not because of have better understand of customer's behaviour in different way to segment, but also social class also affects taste and life style, and then people have different life style, they also have different way of consumption. Consumers from different background, different income, and different social class tend to have different behaviour. Without considering cultural context which mostly consumers are made, consumer conception cannot be understandable. The cultural aspect of attitude, life style and behaviour is the significantly considerable one of the issues. Therefore, whether in digital marketing or traditional marketing, marketers should take culture into account and understand how the cultural environment where customers live creates the value of products and services. However, D. Hawkins and D. Mothersbaugh have strong statement that the culture seems to not only shape and regulate the priorities customers usually attaches to variety of products and activities, and also it regulates the failure or success of that available services or products [14]. However, actually the relationship between culture and consumer behaviour is responding each other, not only the culture is influencing the customer behaviour. On the other hand, the products and services offered to consumers also take into account the cultural values of people. For example, structure of the family and convenience in providing food services. 


\section{Discussion of Digital Marketing Funda- mentals: Strategy, Implementation and Practice}

In the face of Economic Internationalisation and significantly interconnected world, a great number of industries attempt to introduce their marketing performance globally. As a matter of fact, whether the rapid advancement of digital innovation or social media have been applied in a variety way. However, in the world's rapid economic growth, an successful organisation is not only concerned with the overall scope of marketing competences and how organisations add value to constituent business (how the business should compete with particular market). As well, it is also an organisation's competences effectively deliver value to the consumer. From this point of view, it is necessary to consider strategic marketing capability (tangible resources and intangible resources), and competences (ability, talent, skill and power) of organisation. Notable examples of that is Alibaba group, which is readily made multi-sided platforms to bring buyers and sellers together within its online side. This application of internet and other social media is poses of course a great number of new opportunities and challenges. It is called digital marketing. Before focus on the definition of marketing emphasises, it is necessary to definite definition of marketing. Marketing is the management process for identifying, anticipating, and satisfying customers' requirements profitability. Just what exactly is digital marketing? In addition, if it is new what does it replace? A great number of scholars have defined digital marketing differently. Scholars defined digital marketing as «Achieving marketing objectivities through applying digital technologies.) This statement reminds us the investment in internet marketing is the result of technology.

Although digital marketing has been remarkably effective with its great number of benefits, there are many challenges and limitations, which need to be overcame. For instance, consumers sometimes do face complexity, configuring the campaign, which let consumer's expertise in house or an agency. Moreover, responding to changes in technology, during the digital marketing process, companies should renew and keep up to date with better capability and innovative ideas.

Jack Ma is from humble toots in China; however, today he is a global symbol of business success. $\mathrm{He}$ is the one let the Internet has revolutionized the way Chinese people do business and people's living condition. He started Alibaba with the goal to help SMEs make money through Internet. What is interesting today is not only Chinese people have used Alibaba platform, but also may many American entrepreneurs as well as Europeans have successfully used Alibaba platform to start their own business.

Alibaba group founded in 1999 and headquarter in Hangzhou, China, and is the largest e-commerce company. Alibaba has ten million active sellers on the platform and 267 million active buyers [15], which is more than population of the US, and Canada combined. In the last fiscal year, the GWV and the Alibaba was almost $\$ 400$ billion dollar. Dramatically, $86 \%$ of all goods purchased on mobile phone in China were done on Alibaba group. As it had already mentioned in previous part, Alibaba created Singles Day, which is celebrated on November 11th, which is now the world's largest shopping day. What is interesting is in a single 24-hour period, Alibaba did sale 9.3 billion sales which are more than three and a half times the total E-commerce sales in the US on Black Friday and cyber Monday combined. On average day, 30 million Alibaba packages are delivered. Alibaba group debuted the largest IPO in the world at $\$ 25$ billion [16]. Finally, its founder, Jack Ma, is widely considered one of the most innovative and thoughtful entrepreneurs in the world today or possibly ever.

\section{Alibaba Provides a Global Market for All}

What kind of digital marketing strategy affected Alibaba in terms of customer behaviour? Today, in the crowded digital marketing environment, it is not easy to stand alone with a great number of online advertising options. Therefore, figuring out the best way and digital marketing strategies in terms of consumer behaviour is the key to develop.

Here Alibaba group is taken as an example, which explains this idea. Alibaba group successful e-commerce company, which created a digital e-commerce platform combining small and medium sized companies, suppliers and consumers from China and all over the world. When Jack set up Alibaba in 1999, most of people did not know what the internet is. When he started the e-commerce, no one trusted him that Chinese may accepted in common, because Chinese people did not have trustable system. As a result, of this background they believe that customers are number one, employees are number two, and shareholders are number three.

On February 17, 2004, Alibaba announced in Beijing that it would be raising the large sum of 82 million dollars in strategic investment on digital marketing in terms of consumer behaviour [17]. 
However, in China, it was also difficult to overstate the importance of traditional consumer behaviour in terms of culture, customs and work pattern. Even though the economy of China recorded highest growth rate from 1978 'Great Leap Outwards', there is big gap between highest income zone and urban area. In fact, Alibaba group has been dealing with awesome strategic capabilities depends on customer's behaviour. For instance, in the sense of brand loyalty, Alibaba group invested focuses in Website intelligence, email marketing, social media and online consumer engagement, online reputation management, affiliate marketing and strategic partnership. Obviously, those factors have noticeable impact on customer behaviour. Moreover, Mr Jack Ma mentioned in 2013 global business reference in America that Alibaba is platform where whether companies or small medium sized enterprise could segment customers in terms of social factors of income and physical segmentation [18].

To conclude, how digital marketing strategy affected Alibaba in terms of customer behaviour, digital marketing has negative influences on consumer behaviour, and also use different type of digital technology and social media to target consumers differently. Initially, Chinese consumers are not only affected by brand name, but also company name, concern with price, and brand loyalty. Here, in terms of Alibaba strategy, it can be suggested: «Listen to your customers for information about ways you can expand your product line». As a seller who involved in digital marketing, you have to take advantage of super deal promotion. Another tip for digital marketers [19], if you want to be listed at the top of search result, be sure to describe your product in comprehensive details with very rich content and multiple photos. To remember update your information as frequently as possible with any new information.

Ultimately, Alibaba group online marketing page provides trading information for more than 240 countries. It has more than 40 different industry categories in which you can find anything. Interestingly, Alibaba partners include trade association, third party service and other content providers.

\section{Digital Marketing Impact on Consumers}

We all live in a world that is significantly influenced by marketing whether for better or worse. Therefore, we are surrounded by digital marketing stimuli in the form of advertisement, via email, TV and so on. Alibaba let many small and medium businesses to create and maintain online shops, without the complexity that involved in purchasing and developing an expensive standalone e-commerce software solution. Customers are attracted to shopping on Alibaba. In the questionnaire, it is given specific question to find out how frequently people do access Alibaba platform. Consequently, previous research shows that that the majority of customers do access Alibaba platform three times a week whether they make sure buy products or not. And lower percentage of responders are kind of once a month do online or Alibaba shopping experience. It can be seen that digital marketing activities can be grounded internet advertising, search marketing, email marketing, viral marketing, social media and also mobile marketing [20].

Alibaba is a publicly traded internet based business. The B2B portal allows Chinese manufacturers to connect with overseas manufactories in an attempt to sell more products to their target consumer audience, and to earn more income. In 2014 September, the company was valued at $\$ 231$ billion, meaning it has greatly grown since its inception, and is a safe marketplace for businesses to engage in business, and for consumers to purchase [21].

In fact, digital marketing has positive influences on consumer behaviour. As a matter of fact, those explanations in the section of literature review can be hypothesized that digital marketing in any forms has positive influences on consumer behaviour [22]. Therefore, digital marketing provides the power to not only give all information about specific product or service but also motivate more purchases. Moreover, through digital marketing, consumers also influence other buyers. Additionally, by digital marketing processing, organizations easily can have feedback from online [23].

\section{Conclusion}

The aim of this research topic is to demonstrate and attest the positive influences of digital marketing on the customer behaviour. Available sources were considered, in which initial research evidence identifies and examines how digital marketing affects customer behaviour. It generally described the theoretical framework and a simple model of consumer decision making, consumer value, and satisfaction from consumer behaviour perspective. On top of this, it presented critical examination of market segmentation and illustrated how consumer behaviour provides both the conceptual framework and strategic direction for the practical segmentation of market. Moreover, the study of 
digital marketing is important for understanding and predicting marketing performances in digital age. Digital marketing is concerned with not only marketing itself and segmenting market, but also with taking strategic management decisions. However, digital marketers used consumer research from a positivist or interpretative viewpoint and used various methodologies to study consumer behaviour at every phase of the consumption process. Consequently, consumer behaviour has become an integral part of strategic digital marketing plan. Digital marketing research proved that social media marketing is more important than ever for company products and services online. Therefore, both organisations and SME's use social platforms and rely on it for building customer loyalty, distributing new products, and increasing number of channels. Furthermore, choosing right social media strategy is a key in the success or failure of business, because customers will be looking for specific brand to be responsive and involved in brand information. Examining performance of Alibaba group proved that using digital marketing and corresponding management in the period of Internet and social networks leads to successful business.

\section{References}

1 Kellerman B. What every leaders needs to know about followers, Harvard business review, Vol.85, No.12. - 2007, pp.87-90.

2 Ariely D. and Simonson, L. Buying, building, plying or competing, Journal of psychology, 13(1), - 2003, pp.111-116.

3 Walter, M. Social research methods: an Australian perspective. Melbourne: Oxford University Press. - 2006.

4 Baker R. A Web of worries. Research word, ESOMAR. - 2008.

5 Lee G. Death of 'last click wins': media attribution and the expanding use of media fata, Journal of Direct, data and digital marketing practice, 12(1)-2010, pp. 16-26.

6 Wood S. Business information management, 2nd Ed. Times Prentice Hall, Harlow. - 2010

7 Pickton A., Broderick D. Integrated marketing communications, financial times. Prentice Hall: Harlow. -2001.

8 Wartime K., Fenwich I. Digi marketing - the essential guide to new media and digital marketing. Singapore: John Wiley and Sons. -2008.

9 Young P.V. Scientific social survey research 4th Ed. Englewood: Cliffs, NJ, Prentice Hall Press. - 1966.

10 Hawkins B.C. Consumer behaviour: building marketing strategy. London: McGraw- Hill. - 2001.

11 Rachman S. The evolution of CBT. In D.M. Clark \& C. Fariburn, the science and practice of CBT. Oxford: Oxford University Press. -1997.

12 Halvorson K. Content strategy for the web, New Riders, 1249 Eight street, Berkeley, CA. - 2010.

13 Ott A. Time value economics: competing for customers time and attention, Strategy and leadership. 39(1) - 2011, pp. 24-44.

14 Hawkins D., Mothersbaugh D. Consumer Behavior: Building Marketing Strategy, 12th Edition. McGraw-Hill Education.2012.

15 Chaffey D. Digital Business and E-Commerce Management. 5th Ed. United Kingdom: Pearson Education Limited. - 2015

16 Financial Times (n/n) Defination of digital marketing [Online]. Available at: http://lexicon.ft.com/Term?term=digital-marketing. Accessed: 10th Nov - 2015.

17 Zheng Z. How to create uncontested market space. Qinghua. - 2013

18 Wang C. The study of Alibaba (阿里巴巴的企业战略). Chen Zhen Press. - 2014.

19 Richins M.L. () Special possessions and the expression of material value. Journal of consumer research. - 1994, pp.511-3

20 Thyer B. A. Single system research design. Peacock. -1993, pp.98-111.

21 Wells A. Metacognitive therapy for anxiety and depression. Chichester: Wiley. -2009.

22 Tashakkori A., Charles T. Handbook of mixed methods in social and behaviour al research. Thousand Oaks: CA, Sage. 2003

23 Stewart J. The psychology of decision making. Decision Making: an Integrated Approach. London: Pitman. - 1994.

\section{References}

1 Ariely D. and Simonson L. (2003) Buying, building, plying or competing, Journal of psychology, 13(1), 111-16.

2 Baker R. (2008) A web of worries. Research word, ESOMAR, 2008

3 Chaffey D. (2015) Digital Business and E-Commerce Management. 5th Ed. United Kingdom: Pearson Education Limited.

4 Financial Times (n/n) Defination of digital marketing [Online]. Available at: http://lexicon.ft.com/Term?term=digital-marketing. Accessed: 10th Nov, 2015

5 Halvorson K. (2010) content strategy for the web, New Riders, 1249 Eight street, Berkeley, CA.

6 Hawkins B.C. (2001) Consumer behaviour : building marketing strategy. London: McGraw- Hill.

7 Hawkins D., Mothersbaugh D. Consumer Behavior: Building Marketing Strategy, 12th Edition. McGraw-Hill Education. 2012.

8 Kellerman B. (2007) What every leaders needs to know about followers, Harvard business review, Vol.85, No.12. pp.87-90. 
9 Lee G. (2010) Death of 'last click wins': media attribution and the expanding use of media fata, Journal of Direct, data and digital marketing practice, 12(1), 16-26.

10 Ott A. (2011) Time value economics: competing for customers time and attention, Strategy and leadership. 39(1), 24-44.

11 Pickton A. and Broderick D. (2001) Integrated marketing communications, financial times. Prentice Hall: Harlow.

12 Rachman S. (1997) The evolution of CBT. In D.M. Clark \& C. Fariburn, the science and practice of CBT. Oxford: Oxford University Press.

13 Richins M.L. (1994) Special possessions and the expression of material value. Journal of consumer research, pp.511-3

14 Stewart J. (1994) The psychology of decision making. Decision Making: an Integrated Approach. London: Pitman.

15 Tashakkori A. and Charles, T. (2003) Handbook of mixed methods in social and behaviour al research. Thousand Oaks: CA, Sage.

16 Thye B. A. (1993) Single system research design. Peacock, pp.98-111.

17 Walter M. (2006) Social research methods: an Australian perspective. Melbourne: Oxford University Press.

18 Wang C. (2014) The study of Alibaba (阿里巴巴的企业战略). Chen Zhen Press.

19 Wartime K. and Fenwich, I. (2008) digi marketing- the essential guide to new media and digital marketing. Singapore: John Wiley and Sons.

20 Wells A. (2009) Metacognitive therapy for anxiety and depression. Chichester: Wiley

21 Wood S. (2010) Business information management, 2nd Ed. Times Prentice Hall, Harlow.

22 Young P.V. (1966) Scientific social survey research 4th Ed. Englewood: Cliffs, NJ, Prentice Hall Press.

23 Zheng Z. (2013) How to create uncontested market space. Qinghua Press. 